Environment Conservation Journal 15(1 \& 2)177-184, 2014

ISSN 0972-3099 (Print) 2278-5124 (Online)

Abstracted and Indexed

\title{
Integrated modified anaerobic baffled reactor with aerobic post treatment for nutrient removal from aquaculture wastewater
}

\author{
Valsa Remony Manoj ${ }^{1} \bowtie$ and Namasivayam Vasudevan ${ }^{2}$
}

Received: 01.11.2013

Revised: 19.02.2014

Accepted: 02.04.2014

\begin{abstract}
The present study is an attempt for treatment of aquaculture wastewater from indoor facilities such as hatcheries etc through integrated process. which comprises an anaerobic baffled reactor (ABR) packed with coconut coir fibre as bacterial support medium and an aerobic cascading step to aerate the effluent coming out of the anaerobic baffled reactor. The maximum COD removal obtained in coconut coir packed ABR was $96 \%$ while in the control, it was $65 \%$. The maximumTotal Kjeldahl Nitrogenremoval in coconut coir packed ABR was $95 \%$ while in the control ABR the removal was $61 \%$. The maximum percentage ammonia removal obtained in coconut coir packed ABR was $97 \%$ while in the control ABR $95 \%$ of ammonia removal was achieved. Therefore the study concludes that the process significantly reduces the nutrient load in the wastewater making it suitable for release into natural water bodies or for recirculation.
\end{abstract}

Keywords: Aquaculture, anaerobic baffled reactor, cascade aeration, nitrogen removal, sustainability, wastewater treatment

\section{Introduction}

In India, one of the major activities for economic sustenance of communities along coastal areas is Aquaculture. India's coastline extends to $8,118 \mathrm{~km}$ with 2.02 million $\mathrm{km}^{2}$ of exclusive economic zone. Much of aquaculture practiced in India ranges from semi-extensive to extensive. In India, export of marine products during the first three months of the year 2008-2009 recorded a growth of $5.26 \%$ in dollar earnings. Quantity of aquaculture products exported in 2008 was 10276.7 million tonnes (Manoj and Vasudevan, 2009). A predominant percentage of culture production is that of Tiger shrimp (Penaeus monodon), followed by white shrimp (Penaeus indicus) and banana shrimp (Penaeus merguensis). Farmed shrimp is the most profitable commodity and also the most polluting (Naylor et al. 2000), (Treece, 2002). Pollution from aquaculture is a serious issue. Intensive coastal aquaculture leads to low dissolved oxygen, highnutrient, organic, metabolic and microbial loads from dissolved, particulate organic compounds, faeces, unutilized feed. One tonne of produced fish generates $0.8 \mathrm{~kg}$ of nitrogen/day and $0.1 \mathrm{~kg}$ of phosphorus/day (Suzuki et al, 2003). Removal of carbonaceous and nitrogenous pollutants before

Author's Address

${ }^{1}$ Deptt. of Chemistry, Velammal College of Eng., Chennai

${ }^{2}$ Centre for Env. Studies, Anna University Chennai, Chennai

Email: chemistry.manoj@ velammal.edu.in

Copyright by ASEA

All rights of reproduction in any form reserved discharging the wastewater into a water body is essential to avoid oxygen depletion and eutrophication (Sudarno, et al. 2010). The aquaculture industry has been challenged to develop economically viable systems that not only produce species at high density but also must contend with limitations because of location, water availability and environmental impact among others (Schreier. et al. 2010). Traditional nitrification/ denitrification systems are the most developed and applied technology for nitrogen removal worldwide (Paredes, et al. 2007). To maintain healthy ecosystem in aquaculture ponds, bioremediation in zero exchange and integrated recirculating systems and treatment of wastes prior to discharge are the best eco-friendly practices (Krishnani et al, 2010). In India, recirculation technologies are not popular owing to the fact that much of brackish water shrimp aquaculture is still largely practiced as a semi-intensive enterprise. Owing to this unique scenario, it should be considered important to combine the concepts of recirculation technologies, especially for the treatment of nitrogenous wastes. The implementation of systems such as attached growth bioreactors would primarily require appropriate and easily available material to economize the cost of conventionally used synthetic bacterial support medium. Development 
of an effective, low-cost treatment is therefore imperative if aquaculture is to expand continually at the present rate (Zachritz and Jacquez, 1993). Anaerobic wastewater treatment processes are attractive, especially for high strength and warm temperature wastewaters. They are capable of responding quickly to wastewater feed after long periods without substrate addition. An appropriate anaerobic wastewater treatment unit that is known for it's performance and decentralized potential is the anaerobic baffled reactor (ABR), it is a compartmentalized reactor consisting of hanging and standing baffles to force the effluent being treated to flow over (or through) and under from the inlet to the outlet of the reactor. ABR is a high rate bioreactor which has numerous advantages over other reactors and these includes, better resilience to hydraulic and organic shock loadings, longer biomass retention times, lower sludge yields and the ability to partially separate the various phases of anaerobic catabolism. The most significant advantage of the ABR is its ability to separate acidogenesis and methanogenesis longitudinally down the reactor. By integrating in tank baffles, a better contact can be achieved between the wastewater and the active biomass (sludge), leading to increased treatment efficiencies. Lab, pilot and full scale work has shown that the ABR is capable of treating a variety of wastewaters of varying strength $(0.45<1000 \mathrm{~g} / \mathrm{l})$ - over long loading rates $10.4<28 \mathrm{Kg} / \mathrm{m}^{3} \mathrm{~d}$. The unique advantages of the anaerobic baffled reactor system are its simple design, low capital and operational costs, and low sludge generation. Bachmann et al. (1985) developed the anaerobic baffled reactor (ABR) in order to obtain an improved performance of high strength treatment process in anaerobic reactors. This is achieved by the separation between the acidogenesis and methanogenesis (Anderson, et al. 1994). The ABR encourages phase separation along the length of the reactor (Barber and Stuckey, 1999).The present study aimed at providing an integrated solution for wastewater treatment and recirculation of treated wastewater which is particularly useful for aquaculture operations / systems. The study is intended depending on scale up for indoor and outdoor aquaculture such as hatcheries, extensive, semi-extensive, intensive and indoor shrimp farms. The wastewater treatment system uses naturally available material as biological support for the growth of microorganisms involved in the treatment system. The system includes a compartmentalized anaerobic baffled that include a preliminary sedimentation chamber followed by four compartments packed alternatively with coconut coir as organic support medium. The system then follows up with a post-anaerobic treatment unit which eliminates ammonia to below toxic levels to aquatic life forms being cultured. The system is thus an integrated unit which can expel or recirculate the treated wastewater. The system specifically treats COD, TKN and Ammonia to below detectable limits. This system is unique in it's incorporation of the specific type organic support media used and an extent of the removal of nutrients to an extent not previously seen in these types of reactors. The system is also unprecedented in it's mode of purpose for treatment and recirculation of treated aquaculture wastewater. The system also greatly reduces the number of separate units hitherto described in conventional recirculating aquaculture systems.

\section{Material and Methods}

A slightly modified ABR design was used the laboratory scale ABR with four compartments had a dimension of $27.94 \quad \mathrm{~cm} \quad x \quad 12.7 \quad \mathrm{~cm} \quad \mathrm{x}$ $33.7 \mathrm{~cm}$, totalling to a volume of 11.9 Litres $\left(0.0119 \mathrm{~m}^{3}\right)$. In the present design, the settling chamber was placed first followed by the other compartments. Coconut coir was packed into the chambers excluding the settling and the last chambers. The influent tank used had a capacity of 20 L. A peristaltic pump was used to regulate a steady flow rate of $6 \mathrm{~L} /$ day from the influent tank to the ABR. The HRT was maintained at $48 \mathrm{~h}$ corresponding to the volume of the reactor. Single gas port was provided in order to collect the released gas by water displacement method. The experimental setup is shown in Fig 1. A control reactor without packing was also setup. Nutrient removal studies were conducted and samples were analyzed on weekly basis. For consistency in the nutrient removal studies under laboratory conditions, it was deemed necessary to use synthetic wastewater after an initial start-up using field aquaculture wastewater. The composition of the simulated wastewater used was adopted from 


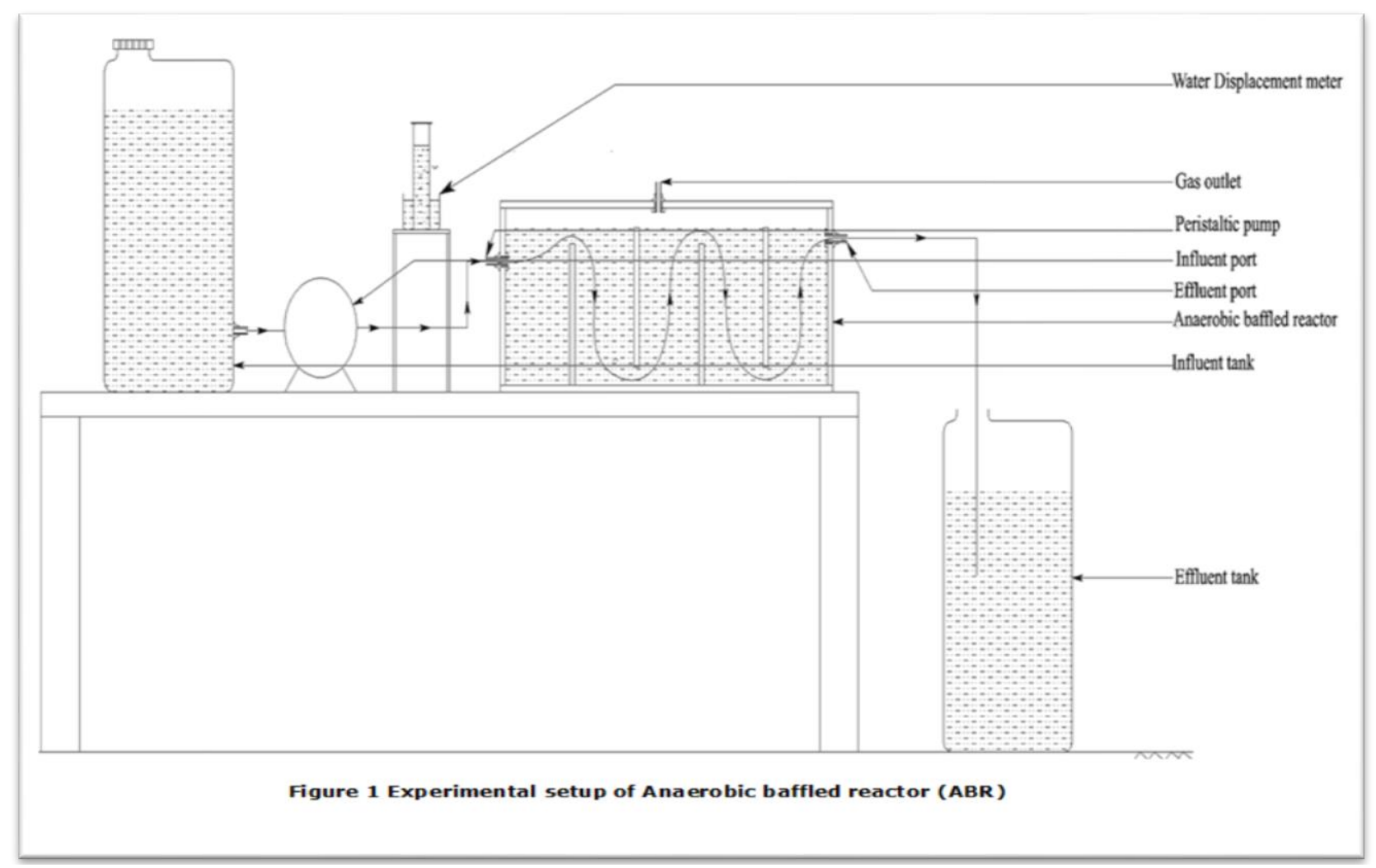

Table 1 Composition of simulated wastewater

The composition of the simulated wastewater used is listed in Table 1. A post anaerobic treatment was carried out following the treatment of the wastewater in the anaerobic baffled reactor. The treatment was done for re-oxygenating the effluent and in the process, to remove residual ammonia to permissible levels. Aeration by cascading method was run for this purpose. A thermocole sheet of 4" $x 3$ " was divided into three equilateral sections with a tapering outlet at one end. Pebbles were placed uniformly along the length of the inclined sheet to promote diffusion of air bubbles for aeration. The effluent was allowed to flow through with some resistance to a collection tank by force of gravity, creating turbulence as the wastewater flows down a series of pebbles. The experimental setup is shown in Fig 2.The parameters influencing the efficiency of the cascading procedure are the initial dissolved oxygen level, required discharge dissolved oxygen and wastewater temperature.

\begin{tabular}{|l|l|}
\hline \multicolumn{1}{|c|}{ CHEMICAL } & \multicolumn{1}{|c|}{ g/l } \\
\hline Sodium chloride & 10.547 \\
\hline Potassium chloride & 0.287 \\
\hline Sodium bicarbonate & 0.0719 \\
\hline Magnesium sulphate & 2.695 \\
\hline Magnesium chloride & 1.994 \\
\hline Calcium chloride & 0.445 \\
\hline $\begin{array}{l}\text { Potassium nitrate } \\
\text { Potassium di-hydrogen phosphate }\end{array}$ & 0.728 \\
\hline $\begin{array}{l}\text { Distilled water } \\
\text { Methanol was added as a source of carbon contributing to the COD at } \\
\text { a rate of 1.5 grams of COD/gram of Methanol. }\end{array}$ \\
\hline
\end{tabular}




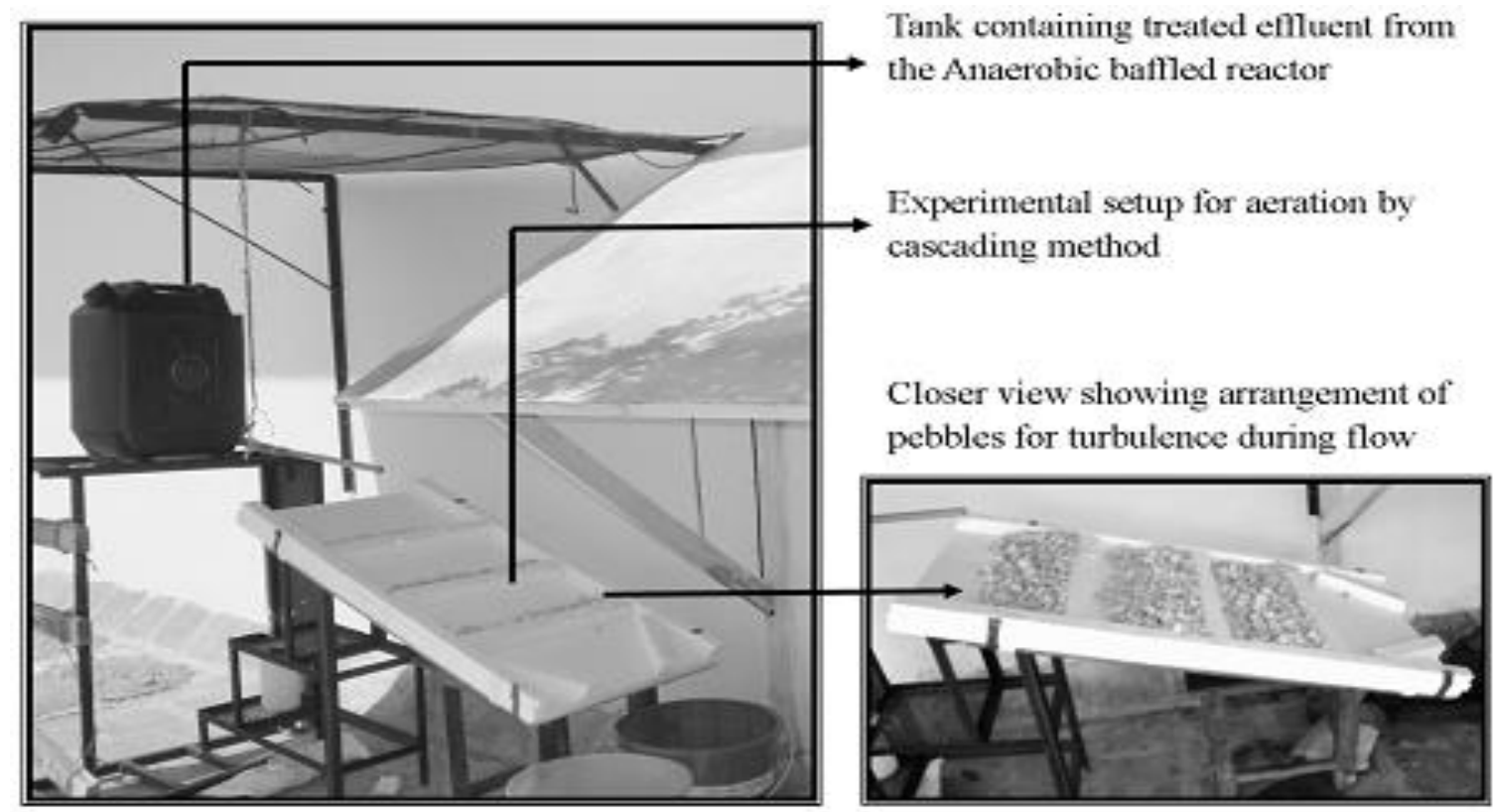

\section{Figure 2 Experimental setup of the cascading system}

The desired dissolved oxygen level was achieved using the equation given by Barrett et al. (1960):

$$
\mathrm{H}=\frac{\mathrm{R}-1}{0.361 \mathrm{ab}(1+0.046 \times \mathrm{T})}
$$

where: $\mathrm{R}=$ deficit ration $=\frac{\mathrm{C}_{\mathrm{s}}-\mathrm{C}_{0}}{\mathrm{C}_{\mathrm{s}}-\mathrm{C}}$

$\mathrm{Cs}=$ dissolved oxygen saturation concentration of the wastewater at temperature $\mathrm{t}, \mathrm{mg} / \mathrm{l}$

Co $=$ dissolved oxygen concentration of the post aeration influent, $\mathrm{mg} / \mathrm{l}$

$\mathrm{C}=$ required final dissolved oxygen level after post aeration, $\mathrm{mg} / \mathrm{l}$

$\mathrm{a}=$ water-quality parameter equal to 0.8 for a wastewater-treatment plant effluent

$\mathrm{b}=$ weir geometry parameter for a weir,

$b=1.0$, for steps, $b=1.1$; for step weir, $b=1.3$

$\mathrm{T}=$ water temperature, ${ }^{\circ} \mathrm{C}$

$\mathrm{H}=$ height through which water falls, $\mathrm{m}(\mathrm{ft})$.
According to the above equation, theoretically the cascading aeration system's height required to aerate initial dissolved oxygen of $3 \mathrm{mg} / \mathrm{l}$ to an increased level of $7 \mathrm{mg} / \mathrm{l}$ at a temperature of $28^{\circ} \mathrm{C}$ is 5.5 metres or 16.4 feet. However, due to space constraints, the laboratory scale cascading unit was limited to a height of only 1 metre. The theoretical height was therefore simulated by recycling the treated water through the cascading unit until the targeted dissolved oxygen level was reached.

\section{Results and Discussion}

COD removal was observed in both plain and coconut coir packed ABR. After startup of the anaerobic baffled reactor, an interesting observation was that the ABR with coconut coir packing showed much greater stability during the transition to simulated wastewater than the control ABR. This ratifies the significant contribution of the organic matter in the coir towards a more stabilized biochemical reaction within the reactor, due to the possible availability of extra carbon from the coconut coir fibre. Here, there was a marked appreciation of COD removal in the coconut coir filled ABR in comparison with the plain ABR. The maximum percentage COD removal obtained in coconut coir packed ABR was $96 \%$ while the plain 
ABR only obtained $65 \%$ of removal. On an average however, the COD removal was $75 \%$ in coconut packed $\mathrm{ABR}$ and $31 \%$ in plain $\mathrm{ABR}$. Results are shown in Fig 3.Previous literature has reported COD removal rates of upto $85 \%$ without organic support. Boopathy (1998) has reported a maximum COD removal of $78 \%$ in a 5compartment ABR without organic support treating swine wastewater. While expounding his results, Boopathy (1998) has summarized that an anaerobic baffled reactor holds much promise as it combines the advantages of the anaerobic filter, which has high stability and reliability, and the upflow anaerobic sludge process in which microbial mass itself functions as the support medium. Koottatep $e t$ al (2003) have reported a maximum COD removal $86 \%$ for a 2-compartment ABR without filter and upto $86 \%$ COD removal for a 2 -compartment ABR with filter in their demonstration of ABR's potential as a decentralized wastewater treatment system in tropical countries. Bodik et al (2002) have described upto $80 \%$ COD removal using an ABR with primary and penultimate sedimentation tanks and compartments filled with plastic tubes serving as filter. Dama, et al. (2001) have noted a higher COD of between 70-90\% removal in domestic wastewater treatment using ABR without filter at a 20 day HRT. Barber and Stuckey (2000) in their review on ABR's; have noted that the principal factors affecting COD removal in ABR's is the effect of low temperature and startup loading rates. Nachaiyasit and Stuckey (1997) observed a $20 \%$ drop in COD removal over a month when the temperature was dropped to $15^{\circ} \mathrm{C}$. The reason attributed to the increased COD removal at ambient temperature of around $35^{\circ} \mathrm{C}$ has been the compliance with the Van't Hoff rule about the doubling of biochemical reactions relatively for every $10^{\circ} \mathrm{C}$ rise in temperature. The present study was carried out at a tropical temperature varying between $30^{\circ} \mathrm{C}$ to $37^{\circ} \mathrm{C}$ during the course of the study with no apparent drop in temperature. The higher COD removal even at average rates $(75 \%)$ using coconut coir fibre as organic support demonstrates the significant advantage over other conventionally operated ABR's.TKN removal was observed in both plain and coconut coir packed ABR. The results with respect to TKN removal clearly show a trend of increased capacity for nutrient removal in organic medium supported
ABR when compared to the conventional plain ABR. This trend followed right from the initial period of startup to the stabilization period of the reactor until reaching maximum percentage removal. The maximum percentage TKN removal obtained in coconut coir packed ABR was $95 \%$ while the plain ABR only obtained $61 \%$ of removal. On an average, the percentage removal was $57 \%$ in coconut packed ABR and $38 \%$ in plain ABR. Results are shown in Fig 4.Koottatep, et al. (2003) has reported a TKN removal of $41 \%$ from domestic wastewater in acompartment ABR. They have reported that their TKN removal was independent of influent TKN concentrations. Boopathy (1998) reported a TKN removal of $52 \%$ whilst treating swine wastewaterusing a 2 compartment ABR. Specific studies on nitrogen removal using $A B R$ have been carried out by Barber and Stuckey (2000) and Bodik, et al. (2002).Ammonia removal was observed in both plain and coconut coir packed ABR.

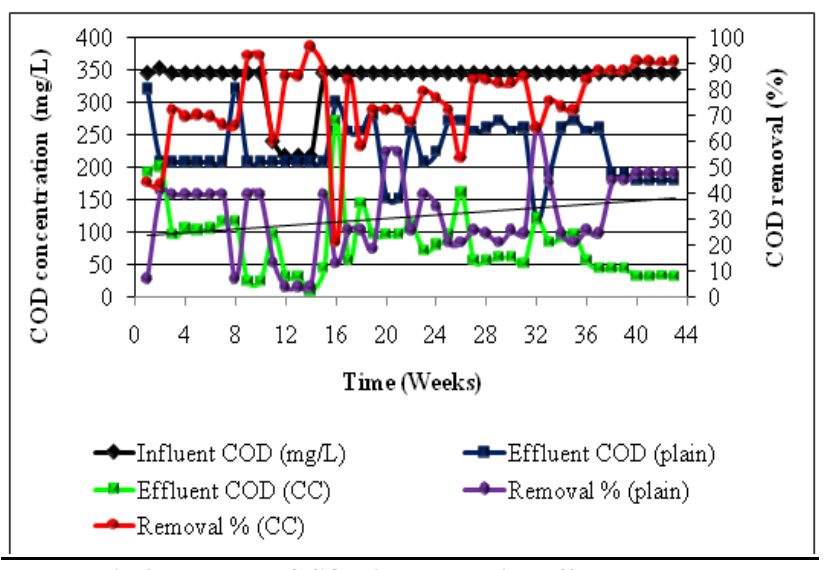

Fig 3 Removal of COD in anaerobic baffled reactor

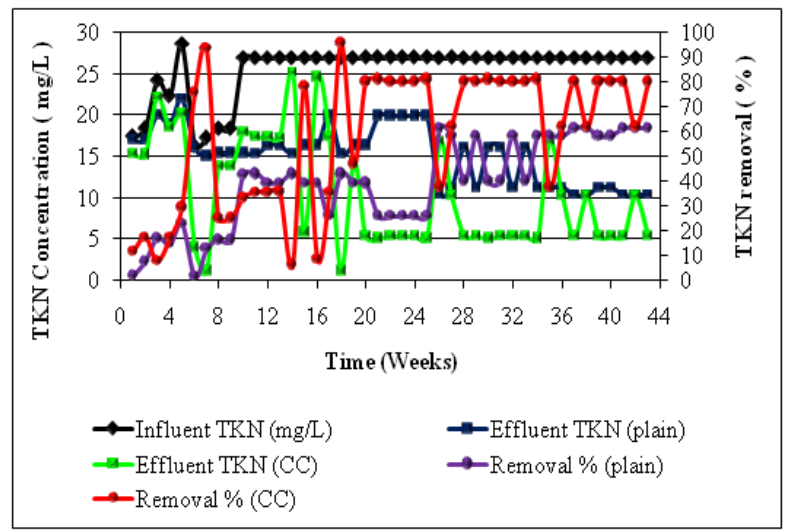

Fig 4 Removal of TKN in anaerobic baffled reactor 
The maximum ammonia removal obtained in coconut coir packed ABR was $97 \%$ while in plain $\mathrm{ABR}, 95 \%$ of removal was observed. On an average, the removal was $82 \%$ in coconut packed $\mathrm{ABR}$ and $72 \%$ in plain ABR. Bodik, et al. (2002) reported an ammonia removal of up to $87.3 \%$ in winter conditions using ABR for treatment of domestic wastewater. Results are shown in Fig 5. The ABR incorporated filter in the form of hanging polypropylene cords and also included an aerobic post-treatment system. It is to be observed with some diligence here that Ammonia was available directly from the influent only during the startup perio from raw wastewater. Continued presence of ammonia in the effluent after the startup period indicates the generation of ammonia within the anaerobic regions which is a common phenomenon known as Dissimilatory Nitrate assimilation (DNRA). This assumption supports the reason for residual ammonia and the evidence for the processes of nitrification and
denitrification.At the conclusion of the studies of nutrient removal using anaerobic baffled reactor $(\mathrm{ABR})$, the reactor was de-commissioned and photographs taken to demonstrate the effect of exposure to nutrients. The photographs are shown in Fig 6.

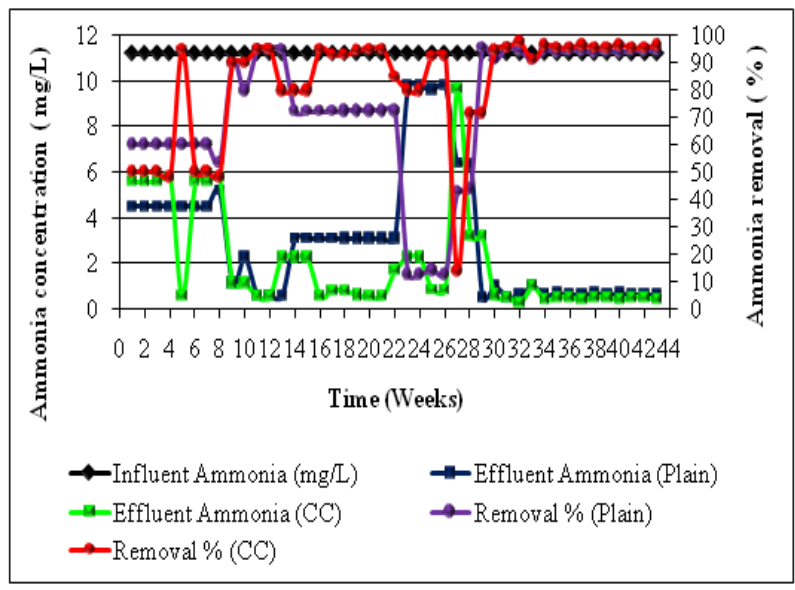

Fig 5 Removal of Ammonia in anaerobic baffled

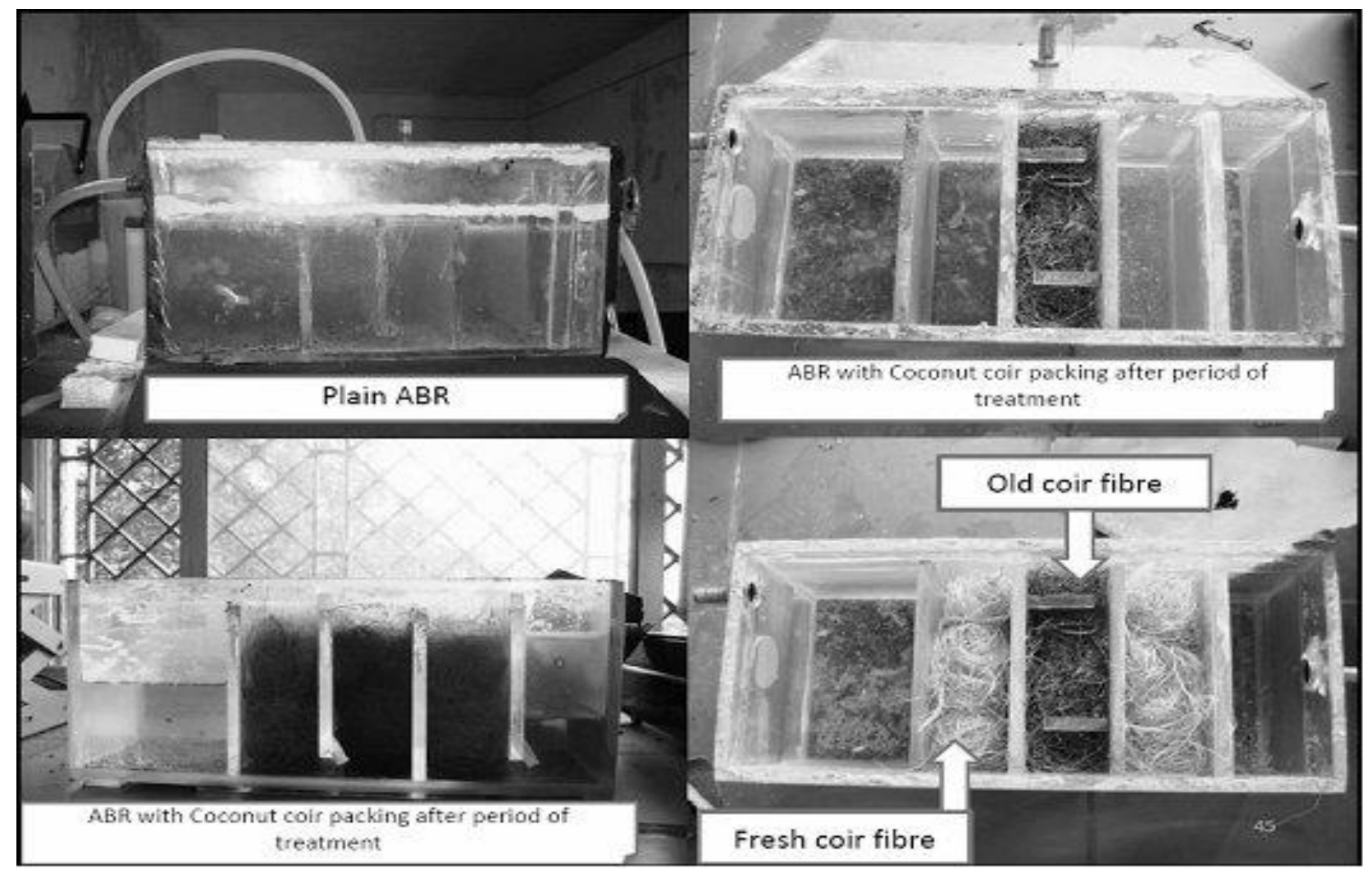

Fig 6 Photographs of the anaerobic baffled reactor after 43 weeks of operation 
Post anaerobic treatment by cascade aeration: Amongst the three methods available for post aeration namely cascade aeration, mechanical aeration and diffused air; cascading method is the least expensive method to raise dissolved oxygen levels (Metcalf and Eddy,2003).Following the treatment of the wastewater in the anaerobic baffled reactor, the effluent from the secondary influent was led to an inclined cascading system where the effluent was allowed to flow through with some resistance to a collection tank by force of gravity, creating turbulence as the wastewater flows down a series of pebbles. The intent of such post aeration steps is to ensure that the effluent poses no immediate depression to the prevailing dissolved oxygen levels upon release to receiving water bodies. Residual ammonia removal from $0.5 \mathrm{mg} / \mathrm{l}$ to an undetectable level $(<0.1 \mathrm{mg} / \mathrm{l})$ was achieved by the process of cascade aeration. The removal of ammonia was coupled with a concomitant increase in the dissolved oxygen from $0.5 \mathrm{mg} / \mathrm{l}$ from the effluent of the ABR to the targeted dissolved oxygen level of 7.8 to $8 \mathrm{mg} / \mathrm{l}$. However, this targeted dissolved oxygen is quite high and in conventional practice, it may be sufficient to bring the dissolved oxygen levels to upto $4 \mathrm{mg} / \mathrm{l}$. A case in point here is that aeration by use of an air compressor would de-necessitate the need for such a cascading arrangement. However, the method proposed here of having a cascading slope offering turbulence to the exiting effluent can be reoxygenated with the simple use of gravity and is a point for sustainable energy efficient practice. On the whole, the aim of this experiment to remove residual ammonia and re-oxygenate the effluent were achieved. All other parameters were observed to well within the permissible limits, except for phosphate which only reduced to only around $50 \%$ from the initial $(18 \mathrm{mg} / \mathrm{l})$. However, it is to be noted that phosphate removal could be achieved under prolonged operation of the anaerobic bioreactor by the phenomenon of "luxury phosphorus uptake"). Until such time, it would be necessary for the inclusion of a bioreactor unit proceeding the ABR to remove the phosphate, or phyto-treatment post ABR. Phosphate uptake due to the phenomenon of "luxury phosphate uptake" by the denitrifying population within the bioreactor can be deemed possible when the bioreactor operates continually at maximum denitrification capacity. Maximum nitrate removal in the ABR during this study period was $91 \%(120 \mathrm{mg} / \mathrm{l}$ to $10 \mathrm{mg} / \mathrm{l})$. Cascade aeration in this case can therefore be attributed as a method of ammonia stripping, where the droplets of water to be treated come into contact with large quantities of ammonia free air due to the turbulence created during down flow in the cascading unit across pebbled surface. At any given time, the quantity of ammonia desorbed from a solution depends on (a) concentration of undissociated ammonia, (b) gasliquid surface area, (c) mass-transfer coefficient, (d) partial pressure exerted by ammonia in the gas phase (Srinath and Loehr, 1974). In general, the removal efficiency depends on the temperature, size, proportions of the facility, and the efficiency of the air-water contact (Metcalf and Eddy,2003). This post anaerobic treatment of aerating the effluent ensures that the nutrients in their reduced forms do not recombine to toxic forms such as ammonia or sulphide.

\section{Conclusion}

Coconut coir fibre as support medium was chosen for studies in a laboratory scale anaerobic baffled reactor for nutrient removal of simulated aquaculture wastewater. The maximum COD removal obtained in coconut coir packed ABR was $96 \%$ while the control ABR only obtained $65 \%$ of removal. The maximum TKN removal obtained in coconut coir packed ABR was $95 \%$ while the control ABR only obtained $61 \%$ of removal. On an average, the removal was $57 \%$ in coconut packed ABR and $38 \%$ in control ABR. The maximum percentage ammonia removal obtained in coconut coir packed ABR was $97 \%$ while the control ABR obtained $95 \%$ of removal.On an average, the ammonia removal was $82 \%$ in coconut packed $\mathrm{ABR}$ and $72 \%$ in control ABR. Post-anaerobic treatment studies using aeration by cascading method was used and showed a resumption of dissolved oxygen in the effluent from ABR by upto $7.8 \mathrm{mg} / \mathrm{l}$. The findings of this study demonstrate that the ABR is a suitable sustainable model for aquaculture wastewater treatment and recirculation.

\section{References}

Anderson.G.K., B. Kasapgil and Ince O. 1994. Comparison of porous and non porous media in upflow anaerobic filters when treating dairy wastewater, Water Research.,28 (7):1619-1624. 
Bachmann.A., V.L. Beard and P.I. McCarty. 1985 "Performance characteristics of the anaerobic baffled reactor,Water Research, 19(1): 99-106.

Barber W.P. and D.C. Stuckey. 1999.The use of the anaerobic baffled reactor (ABR) for wastewater treatment: A review, Water Research,33(7):1559-1578.

Barber W.P. and D.C. Stuckey. 2000. Nitrogen removal in a modified anaerobic baffled reactor (ABR): 2, nitrification Water Research. 34: 2423-2432.

Barrett, M. J., A. L. H. Gameson, and C. G. Ogden 1960. Aeration studies at four weir systems. Water and Water Engineering (British) 64:407 .

Bodik.I., K. Kratochvil, E. Gasparikova and M. Hutnan. 2002. Nitrogen removal in an anaerobic baffled reactor with aerobic post-treatment. Bioresource Technology, 86:79-84.

Boopathy, R. 1998 "Biological treatment of swine waste using anaerobic baffled reactors", Bioresoure Technology, Vol.64:1-6.

Dama P., J. Bell, K.M. Foxon, C.J. Brouckaert, H.T. Buckley, V. Naidoo and D.Stuckey. 2001, Pilot-scale study of an anaerobic baffled reactor for the treatment of domestic wastewater, Proceedings. IWA Conference on Water and Wastewater Management in Developing Countries, Kuala Lumpur, Malaysia, 29-31.

Koottatep, T., Wanasen, S., Morel, A., Schertenleib, R. 2004. Potential of the anaerobic baffled reactor as decentralized wastewater treatment system in the tropics. EAWAG, Department for water and sanitation in developing countries (SANDEC), Switzerland.

Krishnani, K.K., V. Kathiravan, M. Natarajan, M. Kailasam and S. M. Pillai. 2010, Diversity of Sulfur-Oxidizing Bacteria in Greenwater System of Coastal Aquaculture, Applied Biochemistry Biotechnology.

Manoj, V.R., Vasudevan. N. 2009. Functional Options for Sustainable Shrimp Aquaculture in India, Reviews in Fisheries Sciences, 17, 3, 336-347.

Metcalf and Eddy. 2003. Wastewater Engineering: Treatment and Reuse, Fourth edition, McGraw-Hills INDIA, ISBN: 007-041878-0.
Nachaiyasit, S. and Stuckey, D.C.1997. The effect of shock loads on the performance of an anaerobic baffled reactor (ABR), 2. Step and transient hydraulic shocks at constant feed strength. Water Research. Vol.31: 2737-2747.

Naylor, R. L. Goldburg R.J. and Primavera J.H.2000. Effect of aquaculture on world fish supplied, Nature, Vol. 409, No.29.

Paredes D., P. Kuschk, T. S. A. Mbwette, F. Stange, R. A. Müller and H. Köser. 2007. New Aspects of Microbial Nitrogen Transformations in the Context of Wastewater Treatment - A Review,Eng. Life Sci. 7(1): 13-25.

Schreier H.J., N. Mirzoyan and K. Saito. 2010. Microbial diversity of biological filters in recirculating aquaculture systems, Current Opinion in Biotechnology 21(3):318-25.

Srinath E.G. and R.C. Loehr.1974. Ammonia Desorption by diffused aeration, Journal of Water pollution control federation. 46(8):1939-1957.

Sudarno U., Stephan Bathe, Josef Winter and Claudia Galler. 2010, Nitrification in fixed-bed reactors treating saline wastewater Applied Microbiology and Biotechnology. 85: 2017-2030.

Suzuki Y., T. Maruyamaa, H. Numata, H. Sato and M. Asakawa. 2003: Performance of a closed recirculating system with foam separation, nitrification and denitrification units for intensive culture of eel: towards zero emission. Aquaculture Engineering 29:165-182.

Treece, G.D. 2002. Shrimp farm effluents. In: Stickney R.R. and McVey J.P. (eds), Responsible Marine Aquaculture, $\mathrm{CAB}$ International, Wallingford, UK.

Xing J., R. Boopathy and A. Tilche 1991. Model evaluation of hybrid anaerobic baffled reactor treating molasses wastewater. Biomass Bioenergy 1(5) 267-274.

Zachritz W.H. and Jacquez, R.B.1993, Treating intensive aquaculture recycled water with a constructed wetlands filter system,In: Moshiri, G.A. (Ed.), Constructed Wetlands for Water Quality Improvement. Lewis Publishers,Boca Raton, 609-613. 